\title{
Students' adoption of Twitter as an information source: An exploratory study using the Technology Acceptance Model
}

\author{
Sultan M. Al-Daihani \\ Department of Library and Information Science \\ College of Social Sciences, Kuwait University, \\ P.O. Box.68168 Kaifan - 71962 KUWAIT \\ e-mail: s.aldaihani@ku.edu.kw
}

\begin{abstract}
This study explores the factors that affect students' adoption of Twitter as an information source. It relies on a modified technology acceptance model (TAM). Data were gathered using a survey of 400 social sciences students from Kuwait University. Structural equation modeling was employed to examine the proposed relationships of six factors-perceived ease of use, perceived usefulness, perceived enjoyment, social influence, behavioral intention, and actual use-on Twitter usage as an information source. The findings show that perceived enjoyment and social influence are stronger predictors of behavioral intention than perceived usefulness. Conversely, perceived ease of use was not significant antecedents of behavioral intention. The study also found that perceived ease of use influences only by perceived enjoyment. As expected, behavioral intention was an important antecedent of actual use. This study was limited to students of the College of Social Sciences at Kuwait University. Additional studies on the use of social media as an information source are recommended. This study is beneficial for higher educational institutions and academic libraries eager to understand the factors that motivate student adoption of Twitter as an information source for educational purposes.
\end{abstract}

Keywords Twitter; Social media; Students; Information sources; Kuwait, Technology Acceptance Model (TAM).

\section{INTRODUCTION}

A Pew report on college students and technology found that 86 percent of undergraduate students surveyed used social media (Smith, Rainie and Zickuhr 2011). Social media has changed the way users can access information, developing interactive tools for information discovery (Heinrichs, Lim and Lim 2011). According to Sin and Kim (2013 p.74), "Students' usage of social media as an information source is a concern for librarians and educators." Students need to enhance their knowledge of how to use these emerging technologies (Hamade 2013).

According to the Global Information Technology Report for 2015, 75.5 percent of the Kuwaiti populations are Internet users, and the country is ranked $4^{\text {th }}$ worldwide in terms of mobile telephone subscriptions (Dutta, Geiger and Lanvin 2015) with the value of 190.3 per 100 population. The report also indicated that on the scale of 1 to 7 of extensiveness of social media use, the population's average score was 5.8. These results indicate a good 
level of information technology infrastructure available in Kuwait, which is expected to have a positive impact in higher education institutions.

Despite these findings, it seems that Kuwaiti higher academic institutions lack initiatives encouraging the use and adoption of social media applications (Al-Daihani 2009; Alajmi 2011). Hamade (2013) found that Twitter was the most popular social media platform among undergraduate students at Kuwait University, which indicated the popularity of social media use among the students. However, it is unclear what factors may affect the adoption of social media, particularly Twitter, as an information source in academic settings.

The Technology Acceptance Model (TAM) adopted from Davis et al. (1989) is used to assess the factors that may influence the adoption of Twitter. The TAM as a research framework is useful to assess or predict users' acceptance of information technology (Davis 1993). The findings of this study are expected to be relevant for universities and academic libraries in their planning to engage Twitter users in information access and integrate Twitter as a tool with their educational information resources.

\section{RELATED LITERATURE}

\section{Social Media as an Information Source}

Social media are evolving as sources of information. Information sources are usually defined as those in which a person seeks information to answer questions or solve problems (Katz 2012); such sources as social media have a role beyond that of library resources, including books or electronic sources (Scale and Quan-Haase 2015). Kim, Sin and Yoo-Lee (2014) found that undergraduate students use social media frequently to discover information. They observed that these types of applications were used daily and in education-related information-seeking contexts. Furthermore, Al-Harrasi and Al-Badi (2014) indicated the multi-faceted positive impact of social media on students, such as the usefulness of finding information.

Sin and Kim (2013) observed the essential role of social media in satisfying the information needs of students. Subsequently, a study conducted by Kim et al. (2014) investigated the use of social media by undergraduate students as information sources. They highlighted the importance of social media in the academic information seeking of students. They also investigated students' approaches to assessing the quality of information retrieved from these social media sources. The study provided a number of recommendations to educators and academic librarians, including the redesign of information literacy programs. Academic librarians could play a valuable role in addressing and satisfying their users' information needs (Zohoorian-Fooladi and Abrizah 2014).

\section{Students' Adoption of Social Media}

Researchers have frequently examined students' adoption of social media (Pinho and Soares 2011). They have also studied the factors that affect students' use of social media on smartphones (Calisir, Atahan and Saracoglu 2013) and students' intention to adopt social media for educational purposes (Dhume, Pattanshetti, Kamble and Prasad 2012). These studies also used TAM as the research framework.

In the research literature concerning the TAM, Twitter adoption by students has already been modeled. Saeed and Sinnappan (2011) studied the adoption of Twitter by 
undergraduate students in an Australian higher education institution. Their research model was based on a modified TAM, which included perceived ease of use, perceived usefulness, behavioral intention, perceived enjoyment, and subjective norms as predictors of Twitter usage.

In another study on the adoption of Twitter in higher education, Saeed, Sinnappan and Markham (2012) examined Twitter usage by two groups of students from two different universities: one in the United States and the other in Australia. The results were compared with a particular focus on analyzing technology acceptance differences between the two groups, based on a modified TAM research model. The research model included constructs measuring perceived ease of use, perceived usefulness, behavioral intention, perceived enjoyment, and subjective norms.

In summary, these studies show that social media are used by students as an information source in the academic context and different factors could play a significant role in social media adoption. In the following section, a number of constructs are defined and used to hypothesize a modified TAM, building on the previous work of other studies, such as Sibona and Choi (2012) and Saeed et al. (2012).

\section{RESEARCH MODEL AND HYPOTHESES}

To measure the affective factors related to students' adoption of Twitter as an information source, the TAM adopted from Davis et al. (1989) is used. The TAM has been adopted in many studies in the field of library and information science. For example, Tri-Agif, Noorhidawati and Ghalebandi (2016) studied the adoption of e-books among higher education students. Zha, Wang, Yan, Zhang and Zha (2015) adopted the TAM to explore the antecedents of information seeking in digital libraries. Moreover, Chen (2015) used the TAM to examine the impact of an information literacy course on student adoption of an academic library Web portal.

The TAM constructs adopted for this study include perceived usefulness, perceived ease of use, and behavioral intention. Although it is based on the work of Saeed and Sinnappan (2011) in their study of Twitter adoption, the TAM was extended in this study to include perceived enjoyment (PE) and social influence (SI). The following sections define all the study constructs, with reference to prior studies, and propose a number of hypotheses investigated in this study. Figure 1 illustrates the research model examined in this research.

\section{Perceived Enjoyment}

According to Rouibah (2008), perceived enjoyment indicates the extent to which using a particular form of technology is perceived to be personally enjoyable. The positive influence of enjoyment on ease of use and intention to use social media platforms is supported by a number of studies. Calisir et al. (2013), for example, noted the effect of perceived enjoyment on the users' perceived ease of use and behavioral intention in their adoption of social media. Saeed and Sinnappan (2011) also indicated the influence of enjoyment as a predictor for students' adoption of Twitter. Allam, Blustein, Bliemel and Spiteri (2012) found a significant association between perceived enjoyment and the behavioral intention to use social tags. Based on this, the following hypotheses are proposed: 
$\boldsymbol{H}_{1}$ : The perceived enjoyment (PE) of using Twitter as an information source has a significant influence on perceived ease of use (PEOU).

$\boldsymbol{H}_{2}$ : The perceived enjoyment (PE) of using Twitter as an information source has a significant influence on behavioral intention (BI).

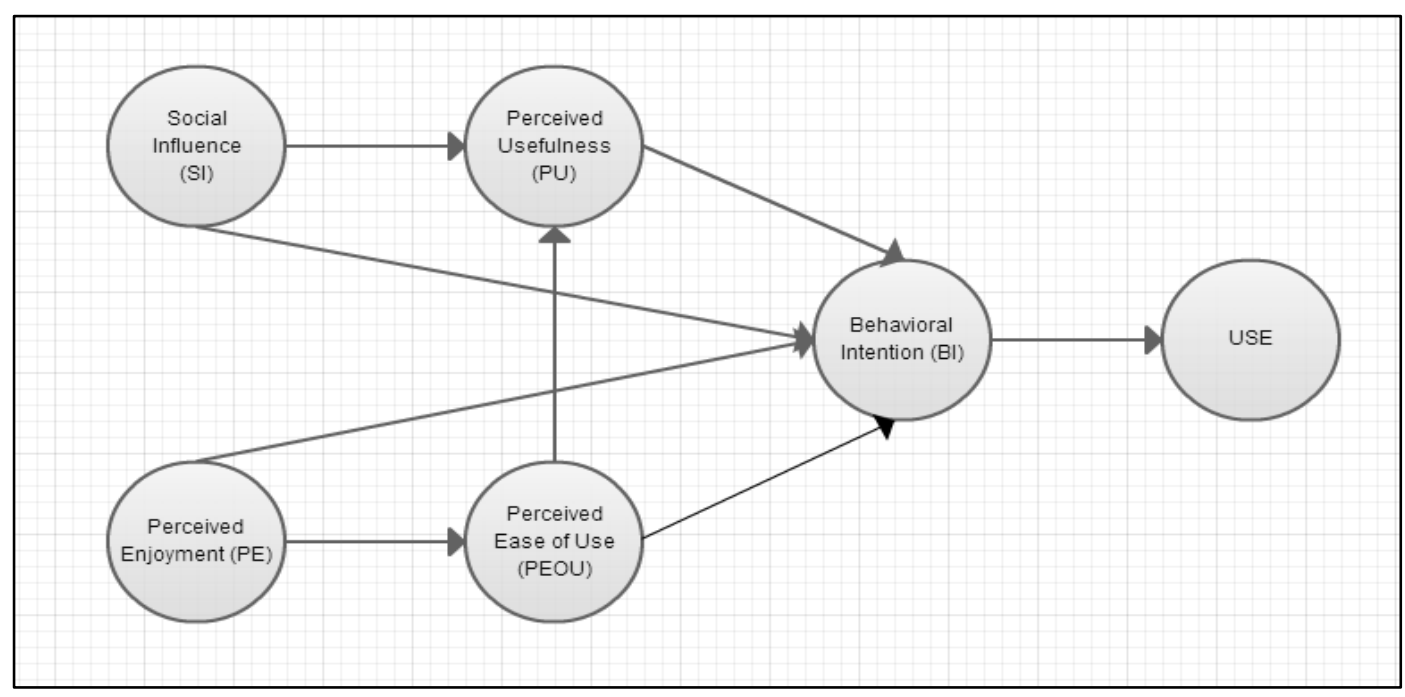

Figure 1: The Research Model

\section{Perceived Usefulness}

Davis (1989 p. 320), defined perceived usefulness as "the degree to which a person believes that using a particular system would enhance his or her job performance." Dhume et al. (2012) argued that perception on using social networking sites is a useful factor because it is a voluntary behavior. Furthermore, Sibona and Choi (2012) found that perceived usefulness was a statistically significant predictor of users' satisfaction on Facebook. More recently, Calisir et al. (2013) also found a positive significant association between perceived usefulness and intention to use a platform in students' adoption of social media. Based on these findings, the following hypothesis was proposed:

$\boldsymbol{H}_{3}$ : The perceived usefulness (PU) of using Twitter as an information source has a significant influence on behavioral intention (BI).

\section{Perceived Ease of Use}

Perceived ease of use is the degree to which an individual expects the use of technology to be free of effort (Davis et al. 1989). Studies have suggested an indirect relationship: ease of use and the intention to use a platform are both mediated by the perceived usefulness of that platform. Evidence from other studies supports this indirect relationship (Davis et al. 1989; Dhume et al. 2012). However, data from other studies suggests that perceived ease of use has a positive significant influence on the intention to use (Kim 2012). Perceived ease of use might also have an influence on perceived usefulness, as hypothesized by Saeed and Sinnappan (2011). Based on these findings, the following hypotheses were proposed:

$\boldsymbol{H}_{4}$ : Twitter's perceived ease of use (PEOU) as an information source has a significant influence on behavioral intention (BI).

$\boldsymbol{H}_{5}$ : Twitter's perceived ease of use (PEOU) as an information source has a significant influence on perceived usefulness (PU). 


\section{Social Influence}

According to Chia (2012), social influence (SI) is the influence of others on the individual's inclination to adopt a technology. Rouibah (2008) argued that, in the Middle East, social influences are a major factor in the adoption of technology. He observed that adoption by individuals is influenced by the perception that those closest to the individual use that technology and expect them to do the same. Therefore, Twitter adoption might be influenced by other students' social influence. Chung (2010) noted that students are constantly aware of and are influenced by their peers' use of technology. Chung also described how individuals are influenced by those with whose opinions they wish or are obliged to comply, such as instructors.

According to Saeed and Sinnappan (2011), subjective norms are an influential factor on students' perceived usefulness and intentions of using Twitter. They argued that students value their peers' perceptions about Twitter use. However, Dhume et al. (2012) observed no influence of subjective norms on attitudes toward social networking sites. They suggested that the adoption of social networking sites is voluntarily for students. Based on these findings, the following hypotheses were proposed:

$\boldsymbol{H}_{6}$ : The social influence $(\mathrm{SI})$ of using Twitter as an information source has a significant influence on its perceived usefulness (PU).

$\boldsymbol{H}_{7}$ : The social influence $(\mathrm{SI})$ of using Twitter as an information source has a significant influence on behavioral intention (BI).

\section{Behavioral Intention}

Behavioral intention to use a social media platform represents the intention one has to use a particular platform or technological arrangement. In both the original and extended versions of the TAM, the intention to use was the only variable that had an effect on actual usage (Calisir et al. 2013). Dhume et al. (2012) found a significant strong association between attitude and intention to use. Based on these findings, the following hypothesis was proposed:

$\boldsymbol{H}_{8}$ : Behavioral intention (BI) of using Twitter as an information source has a significant influence on its actual use (USE).

\section{METHOD}

A survey was used in this study is to examine the research model. The questionnaire contained items adopted and modified from other studies, particularly from Saeed and Sinnappan (2011). The questionnaire included a section about the students' background. Other sections were categorized according to the studied factors - ease of use, enjoyment, usefulness, social influence, behavioral intention, and actual use of Twitter as an information source. A number of items were listed under each category.

To confirm the reliability and validity of the questionnaire before its distribution, 30 subjects were selected from the College of Social Sciences. Based on findings from this pilot test, the questionnaire was modified to the version used in the main study. It was then distributed to the chosen research population of this study-undergraduate students at the College of Social Sciences at Kuwait University-in April 2013.

A total of 420 students responses were received from the 600 questionnaires that were distributed. Twenty incomplete questionnaires were returned; consequently, the total sample size of the survey was 400 students. 


\section{Measurements and Procedures}

The proposed research model (Figure 1), adapted from the TAM, presents the possible influences of two constructs-social influence (SI) and perceived enjoyment (PE)-upon behavioral intention; additionally, it presents the possible influence of perceived usefulness (PU) and perceived ease of use (PEOU) upon behavioral intention (BI), and the possible influence of behavior intention (BI) upon actual use (USE).

The research model constructs were measured using five-point Likert scales from 1 (strongly disagree) to 5 (strongly agree). To fit the study context, the study questions that describe these constructs were adopted and modified from previous studies. A structural equation modeling (SEM) methodology was employed to evaluate the model. SPSS AMOS 20 was used to assess the research model.

\section{RESULTS}

\section{The Measurement Model}

To test the reliability and validity of measures, a confirmatory factor analysis (CFA) was used. The CFA test measures convergent and discriminant validity. To assess the convergent validity, composite reliability, and average variance extracted (AVE) were used. Item reliability should be higher than 0.70 , but levels from 0.60 to 0.70 are considered acceptable in exploratory research (Hair, Ringle and Sarstedt 2011). Table 1 shows that item reliability is higher than 0.70 .

The AVE shows the overall amount of variance accounted for by the original factors: levels of 0.50 or over are considered acceptable (Hair et al. 2011). Table 1 shows that all the AVEs meet this recommendation, ranging from 0.698 to 0.915 .

Table 1: Constructs and Indicators

\begin{tabular}{|c|c|c|c|c|}
\hline Items & Measure/indicator & $\begin{array}{l}\text { Standardized } \\
\text { loadings } \\
(>0.70)\end{array}$ & $\begin{array}{l}\text { Composite } \\
\text { reliability } \\
(>0.70)\end{array}$ & $\begin{array}{l}\text { Average } \\
\text { variance } \\
\text { extracted } \\
(>0.50) \\
\end{array}$ \\
\hline & Perceived Enjoyment (PE) & & 0.919 & 0.695 \\
\hline PE1 & $\begin{array}{l}\text { I experience great pleasure when using Twitter as an } \\
\text { information source. }\end{array}$ & 0.778 & & \\
\hline PE2 & $\begin{array}{l}\text { I feel satisfied when I use Twitter as a source of } \\
\text { information. }\end{array}$ & 0.855 & & \\
\hline PE3 & $\begin{array}{l}\text { I feel pleasure when I use Twitter to search for } \\
\text { information. }\end{array}$ & 0.863 & & \\
\hline PE4 & $\begin{array}{l}\text { I find enjoyment when I use Twitter as an information } \\
\text { source. }\end{array}$ & 0.798 & & \\
\hline \multirow[t]{2}{*}{ PE5 } & Overall, Twitter is fun as a source of information. & 0.876 & & \\
\hline & Perceived Usefulness (PU) & & 0.911 & 0.719 \\
\hline PU1 & $\begin{array}{l}\text { Using Twitter as an information source helps me to } \\
\text { complete my assignments more quickly. }\end{array}$ & 0.840 & & \\
\hline PU2 & $\begin{array}{l}\text { Using Twitter as an information source increases my } \\
\text { learning achievement. }\end{array}$ & 0.837 & & \\
\hline PU3 & $\begin{array}{l}\text { Using Twitter as information source makes it easier for } \\
\text { me to better understand my courses. }\end{array}$ & 0.864 & & \\
\hline \multirow[t]{2}{*}{ PU4 } & $\begin{array}{l}\text { Overall, Twitter as an information source is useful in my } \\
\text { university study. }\end{array}$ & 0.850 & & \\
\hline & Perceived Ease of Use (PEOU) & & 0.817 & 0.600 \\
\hline PEOU1 & $\begin{array}{l}\text { Use of Twitter in learning makes it easier for me to use } \\
\text { it as an information source. }\end{array}$ & 0.785 & & \\
\hline
\end{tabular}




\begin{tabular}{|c|c|c|c|c|}
\hline PEOU2 & $\begin{array}{l}\text { It is easy for me to become skillful in using Twitter as an } \\
\text { information source. }\end{array}$ & 0.846 & & \\
\hline PEOU3 & $\begin{array}{l}\text { Overall, Twitter as an information source use is easy for } \\
\text { me to use. }\end{array}$ & 0.698 & & \\
\hline & Social Influence (SI) & & 0.898 & 0.638 \\
\hline SI1 & $\begin{array}{l}\text { People who are important to me think that I should use } \\
\text { Twitter as an information source. }\end{array}$ & 0.775 & & \\
\hline $\mathrm{S} 12$ & $\begin{array}{l}\text { Students who use Twitter as an information source } \\
\text { enjoy greater recognition from teachers than those } \\
\text { who do not use it. }\end{array}$ & 0.805 & & \\
\hline $\mathrm{SI3}$ & $\begin{array}{l}\text { Students who use Twitter as an information source at } \\
\text { university enjoy better grades than those who do not } \\
\text { use it. }\end{array}$ & 0.803 & & \\
\hline $\mathrm{SI} 4$ & $\begin{array}{l}\text { People whose opinion I value prefer me to use Twitter } \\
\text { as an information source rather than other social media } \\
\text { tools. }\end{array}$ & 0.771 & & \\
\hline \multirow[t]{2}{*}{ SI5 } & $\begin{array}{l}\text { Overall, use of Twitter as an information source will } \\
\text { improve my social image in the college. }\end{array}$ & 0.840 & & \\
\hline & Behavioral Intention (BI) & & 0.937 & 0.789 \\
\hline BI1 & $\begin{array}{l}\text { I plan to always take advantage of the features of } \\
\text { Twitter (hashtag, mentions, lists, etc.) to access } \\
\text { information. }\end{array}$ & 0.837 & & \\
\hline $\mathrm{B} 12$ & I will continue to use Twitter as an information source. & 0.915 & & \\
\hline $\mathrm{BI} 3$ & $\begin{array}{l}\text { I will strongly recommended use of Twitter as } \\
\text { information source use to others. }\end{array}$ & 0.896 & & \\
\hline \multirow[t]{2}{*}{ BI4 } & $\begin{array}{l}\text { Overall, I intend to continue using Twitter as an } \\
\text { information source. }\end{array}$ & 0.904 & & \\
\hline & Actual Use (USE) & & 0.874 & 0.698 \\
\hline USE1 & Rate your level of experience in using Twitter? & 0.781 & & \\
\hline USE2 & What is your rate of use of Twitter? & 0.879 & & \\
\hline USE3 & $\begin{array}{l}\text { Do you prefer to use Twitter rather than other social } \\
\text { media tools? }\end{array}$ & 0.844 & & \\
\hline
\end{tabular}

According to Rouibah (2008), discriminant validity is achieved if there is a higher correlation between the items associated with a measure than with items associated with other measures in the model. Table 2 shows the intercorrelations between the constructs. Overall, the model's convergent and discriminant validity procedures were acceptable.

Table 2: Intercorrelations between Constructs

\begin{tabular}{lllllll}
\hline Construct & USE & PU & PEOU & PE & SI & BI \\
\hline USE & 1.00 & & & & & \\
PU & .23 & 1.00 & & & & \\
PEOU & .31 & .54 & 1.00 & & & \\
PE & .41 & .52 & .70 & 1.00 & & \\
SI & .21 & .44 & .40 & .43 & 1.00 & \\
IN & .27 & .42 & .47 & .57 & .52 & 1.00 \\
\hline
\end{tabular}

\section{Assessing the Goodness of Fit of the Model}

The goodness of fit of the proposed model was assessed using the $\chi^{2}$ (chi-square), GFI (goodness of fit index), AGFI (adjusted GFI), NFI (normalized fit index), CFI (an incremental fit index of improved NFI), and RMSEA (root-mean-square error of approximation). Bentler and Bonett (1980) provide more details regarding these indices.

The fitness measures in the study fell into acceptable ranges (CMIN/DF $=2.93, \mathrm{GFI}=0.84$, $\mathrm{AGFI}=0.82, \mathrm{NFI}=0.87, \mathrm{CFI}=0.93, \mathrm{RMSEA}=0.069$ ). Therefore, this model has the ability to 
describe and anticipate students' adoption of Twitter as an information source. The modified model results in a $\chi^{2}=973.252$, degree of freedom $=332$, and $p$ value $=0.000$, showing that the model fits the data well. Figure 2 shows the research model after testing and modifying the SEM model.

\section{The Structural Model}

The structural model was examined by investigating the relative effect of the path test for the research model constructs: these are shown in Figure 2. The results show that perceived enjoyment (PE) has a significant influence on perceived ease of use (PEOU) $(\beta=$ $0.678, p<0.001)$ and behavioral intention $(\beta=0.373, p<0.001)$, which supports Hypotheses 1 and 2. Perceived usefulness (PU) has significant influence on behavioral intention (BI) $(\beta=.114, p>0.05)$; thus, Hypothesis 3 is supported. Contrary to prior expectation, perceived ease of use (PEOU) had no direct influence on students' behavioral intention (BI) $(\beta=.093, p<0.001)$; therefore, Hypothesis 4 is not supported. Conversely, perceived ease of use (PEOU) does have a significant influence on perceived usefulness (PU) $(\beta=.447, p<0.001)$, thereby supporting Hypothesis 5 . Social influence (SI) has a significant influence on perceived usefulness (PU) and behavioral intention (BI) $(\beta=.312, p$ $<0.001 ; \beta=.295, p<0.001$ ), thereby supporting Hypotheses 6 and 7. Finally, behavioral intention (BI) has a significant influence on actual use (USE) for Twitter as an information source $(\beta=0.359, p<0.001)$, which supports Hypothesis 8 .

Table 3: Results of the Regression Analysis

\begin{tabular}{lllll}
\hline Path & t-value & Sig. & $\boldsymbol{\beta}$ & Results \\
\hline PE --> PEOU & 21.595 & 0.000 & 0.678 & H1 (Supported) \\
PE --> BI & 6.323 & 0.000 & 0.373 & H2 (Supported) \\
PU --> BI & 2.057 & 0.040 & 0.114 & H3 (Supported) \\
PEOU --> BI & 1.799 & 0.073 & 0.093 & H4 (Not Supported) \\
PEOU --> PU & 12.108 & 0.000 & 0.447 & H5(Supported) \\
SI --> PU & 7.397 & 0.000 & 0.312 & H6 (Supported) \\
SI --> BI & 6.056 & 0.000 & 0.295 & H7 (Supported) \\
BI --> USE & 7.043 & 0.000 & 0.359 & H8 (Supported) \\
\hline
\end{tabular}

\section{DISCUSSION}

This study explores the factors associated with undergraduate students' adoption of Twitter as an information source. The research adopted a modified TAM to facilitate understanding of the factors influencing students' adoption of Twitter. The findings indicate that perceived enjoyment (PE) and social influence (SI) appear to have the most significant influence on students' behavioral intention (BI) toward using Twitter as an information source. Further, the perceived usefulness (PU) of doing so also influences the behavioral intention (BI).

A positive relationship was found between perceived enjoyment and ease of use, consistent with previous studies (Calisir et al. 2013). Saeed et al. (2012) concluded that students subsequently adopt Twitter when they derive more enjoyment from the platform. The study's support of Hypothesis 2, on the association between perceived enjoyment and behavioral intention, as this effect appears in previous studies. Saeed and Sinnappan (2011) found that perceived enjoyment (PE) seems to be a major influential predictor of students' intentions to use Twitter. Earlier, Allam et al. (2012) confirmed that perceived enjoyment affected users' intention to use tags in social media. 
As expected, this study found a positive relation between perceived usefulness (PU) and behavioral intention (BI), supporting Hypothesis 3. This study has demonstrated that perceived usefulness is a significant predictor of the behavioral intention of students to use Twitter as an information source. This result confirmed such previous studies as that of Dhume et al. (2012). Kim (2012) also found a positive relationship between perceived usefulness and behavioral intention in the adoption of social media. This study's findings diverge from those of Pinho and Soares (2011), as they found no direct impact of perceived usefulness on intention to use of social networks. They claimed that it might be related to the nature of social media, as it is based on an emotional voluntary adoption by users. Conversely, Saeed and Sinnappan (2011) found an insignificant relationship between the two constructs in their study of Twitter adoption by undergraduate students.

This study's research model suggested that Twitter's perceived ease of use as an information source influences the behavioral intention to actually use it in this way. However, contrary to prior expectation, Hypothesis 4 was not supported. This finding is consistent with Saeed and Sinnappan (2011), who found an insignificant influence of perceived ease of use on behavioral intention. They argued that ease of use is not a determinant of intention to use because of the relative the simplicity of social media platforms. Conversely, Allam et al. (2012) found a significant association between perceived ease of use and intention to use. Saeed et al. (2012) also found a significant influence of the perceived ease of use on the behavioral intention of students to adopt Twitter. Further, perceived ease of use is influential upon perceived usefulness. Calisir et al. (2013) produced a different result in their study of students in Turkey: they found no relationship between perceived ease of use and perceived usefulness.

In the proposed research model, social influence is a determinant of acceptance of Twitter, thus resembling, in this respect, the modified model of Saeed et al. (2012). This may mean that students use Twitter to enhance their social image. Chung (2010) claimed that students are constantly aware of and are influenced by their peers in use of technology. In Kuwait, Rouibah (2008) found social influence to be a major factor in the adoption of technology. However, some studies have found a negative relationship between social influence and adoption. Calisir et al. (2013) claimed that social influence does not have an effect on intention to use a social media platform. Furthermore, Dhume et al. (2012) argued that students use social media voluntarily. Conversely, Saeed et al. (2012) claimed that the positive effect of social influence on students makes them more likely to adopt Twitter.

The behavioral intention factor has a positive association with actual use in this study, in accordance with the previous work of Dhume et al. (2012). However, Calisir et al. (2013), argued that, in reality, behavioral intention may not always be sufficient (without more) to lead an individual to actually access systems. They indicated that actual use might be affected by other social and economic factors. These factors could be considered in future studies of students' adoption of Twitter. Despite these contradictions in the prior studies, the results of this research confirm that behavioral intention is a strong indicator of actual use. 


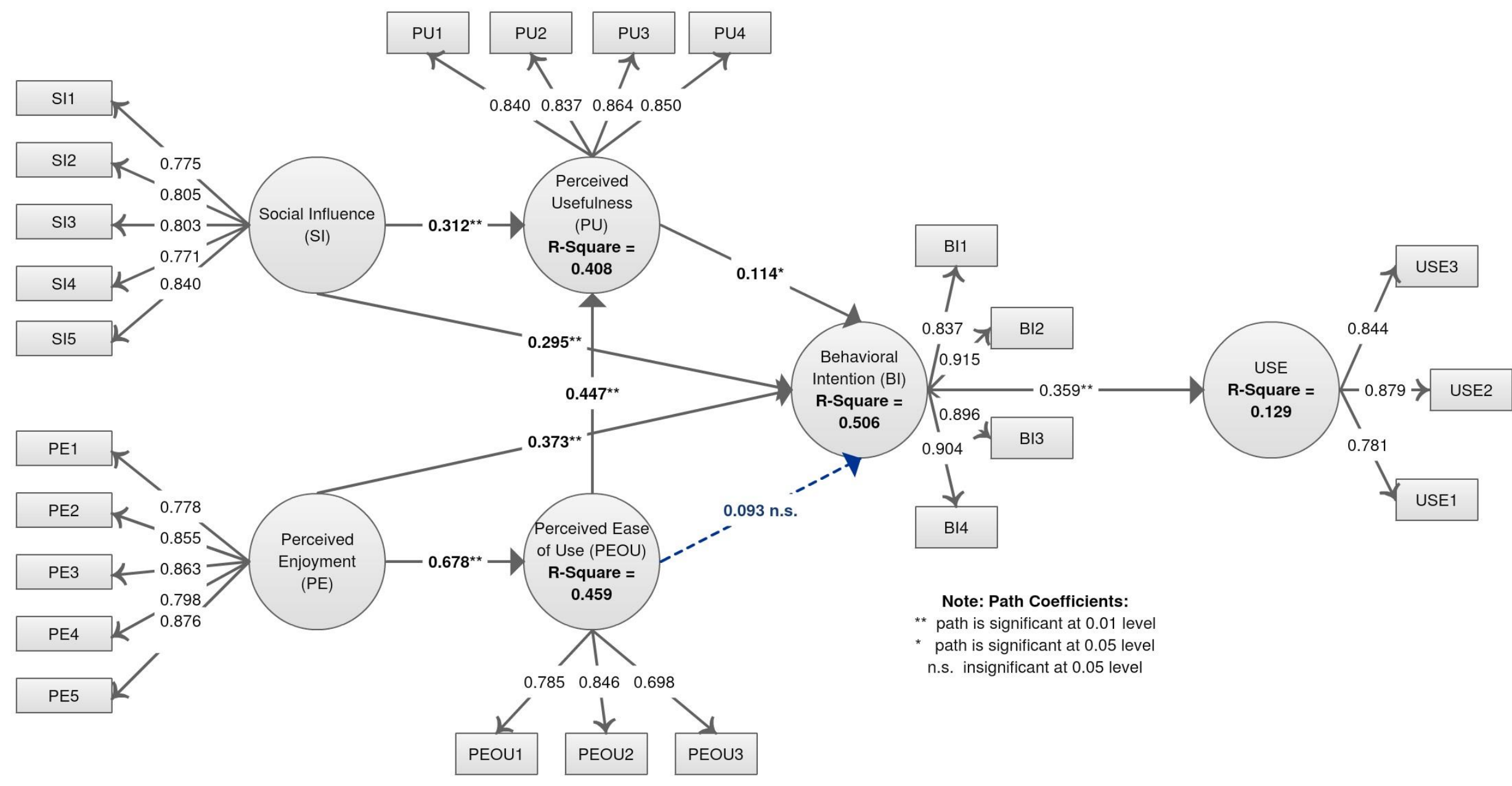

Figure 2: Path Test of the Research Model 


\section{CONCLUSION}

The adoption of Twitter as an information source by Kuwaiti undergraduate students was driven by perceived enjoyment and social influence factors. Therefore, educators and academic librarians should consider planning enjoyable activities and projects around the use of Twitter as an information source. They should also engage active users of Twitter, which in turn is likely to influence their peers and, ultimately increase engagement levels in information access.

The study also reports a significant effect of usefulness, but an insignificant effect of ease of use, on students' intentions to use Twitter as an information source. Thus, it may be worth creating awareness about the usefulness of social media, and particularly Twitter, as an information source among students. As it seems that students are technology savvy, therefore such awareness might be more important than training them on how to use social media for information access. These issues should be taken into account by educators and academic librarians in the designing the related information literacy courses and programs.

The study was limited to students of the College of Social Sciences at Kuwait University, and focused on the adoption of Twitter in particular. Therefore, these results may not be applicable to students of other disciplines or at different higher education establishments and/or to other social media platforms. Future research should use a more comprehensive sample and cover the adoption of other types of social media as information sources. There is a need for deeper understanding of who uses Twitter and for what purposes. Future research should also investigate the topic in depth to compare the influence of teachers' instructions and the study factors on students' adoption of social media in different courses.

\section{ACKNOWLEDGMENT}

The researcher is deeply grateful to the Research Administration, Kuwait University for funding this project $(0107 / 12)$.

\section{REFERENCES}

Alajmi, M. 2011. Modeling student perception of Web 2.0 technologies adoption in Kuwait. (PhD Thesis). University of North Texas.

Al-Daihani, S. 2009. The knowledge of Web 2.0 by library and information science academics. Education for Information, Vol. 27 no. 1: 39-55.

Al-Harrasi, A. S. and Al-Badi, A. H. 2014. The impact of social networking: A study of the influence of smartphones on college students. Contemporary Issues in Education Research, Vol. 7 no. 2: 129136.

Allam, H., Blustein, J., Bliemel, M. and Spiteri, L. 2012. Exploring factors impacting users' attitude and intention towards social tagging systems. Hawaii International Conference on System Science (HICSS) pp. 3129-3138. IEEE. doi:10.1109/HICSS.2012.267

Bentler, P.M. and Bonett, D.G. 1980. Significance tests and goodness-of-fit in the analysis of covariance structures. Psychological Bulletin, Vol. 88: 588-600. 
Calisir, F., Atahan, L. and Saracoglu, M. 2013. Factors Affecting Social Network Sites Usage on smartphones of Students in Turkey. Proceedings of the World Congress on Engineering and Computer Science, Vol II, 23-25 October, San Francisco, USA. Available at http://www.iaeng.org/publication/WCECS2013/WCECS2013_pp1081-1085.pdf

Chen, Y. 2015. Testing the impact of an information literacy course: Undergraduates' perceptions and use of the university libraries' web portal. Library and Information Science Research, Vol. 37 no. 3: 263-274.

Chia, Y.L. 2012. Persuasive messages on information system acceptance: A theoretical extension of elaboration likelihood model and social influence theory. Journal of Computers in Human Behavior, Vol. 29 no. 1: 264-275.

Chung, S. 2010. Factors influencing the use of social media in learning: A case of Wikipedia. In Proceedings of Interactive Computer-aided Learning, Belgium, 2010: 490-500.

Davis, F.D. 1989. Perceived usefulness, perceived ease of use, and user acceptance of information technology. MIS Quarterly, Vol. 3 no. 3: 319-339.

Davis, F.D. 1993. User acceptance of information technology: System characteristics, user perceptions and behavioral impacts. International Journal of Man-Machine Studies, Vol. 38 no. 3: 475-487.

Davis, F.D., Bagozzi, R.P. and Warshaw, P.R. 1989. User acceptance of computer technology: A comparison of two theoretical models. Management Science, Vol. 35 no.8: 982-1002.

Dhume, S. M., Pattanshetti, M. Y., Kamble, S. S. and Prasad, T. 2012. Adoption of social media by business education students: Application of Technology Acceptance Model (TAM). In Technology Enhanced Education (ICTEE), 2012 IEEE International Conference. doi: 10.1109/ICTEE.2012.6208609

Dutta, S., Geiger, T. and Lanvin, B. 2015. The Global Information Technology Report 2015: ICTs for inclusive growth. Available at http://www3.weforum.org/docs/WEF_Global_IT_Report_2015.pdf

Hair, J. F., Ringle, C.M. and Sarstedt, M. 2011. PLS-SEM: indeed a silver bullet. Journal of Marketing Theory and Practice, Vol. 19 no. 2: 139-151.

Hamade, S. 2013. Perception and use of social networking sites among university students. Library Review, Vol. 62 no. 6/7: 388-397.

Heinrichs, J.H., Lim, J.-S. and Lim, K.S. 2011. Influence of social networking site and user access method on social media evaluation. Journal of Consumer Behaviour, Vol. 10 no. 6: 347-355. doi:10.1002/cb.377

Katz, W.A. 2012. Introduction to reference work (8th edition). Boston: McGraw-Hill.

Kim, S. 2012. Factors affecting the use of social software: TAM perspectives. The Electronic Library, Vol. 30 no. 5: 690-706. doi:10.1108/02640471211275729

Kim, K., Sin, S. and Yoo-Lee, E. 2014. Undergraduates' use of social media as information sources. College and Research Libraries, Vol. 75 no. 4: 442-457.

Pinho, J. and Soares, A. 2011. Examining the technology acceptance model in the adoption of social networks. Journal of Research in Interactive Marketing, Vol. 5 no. 2/3: 116-129. doi:10.1108/17505931111187767

Rouibah, K. 2008. Social usage of instant messaging by individuals outside the workplace in Kuwait: A structural equation model. Information Technology \& People, Vol. 21 no. 1: 34-68. doi:10.1108/09593840810860324.

Saeed, N. and Sinnappan, S. 2011. Adoption of Twitter in higher education - a pilot study. In G. Williams, P. Statham, N. Brown and B. Cleland (Eds.), Changing Demands, Changing Directions. Proceedings Ascilite, Hobart, 2011, 1115-1120. Available at http://www.ascilite.org.au/conferences/ hobart11/procs/Saeed-concise.pdf. 
Saeed, N. Sinnappan, S. and Markham, S. 2012. The tale of two cultures: Differences in technology acceptance in Twitter usage. Proceedings of the 23rd Australasian Conference on Information Systems, 3-5 Dec. 2012, Geelong. Available from http://dro.deakin.edu.au/view/DU:30049156.

Scale, M. and Quan-Haase, A. 2015. Categorizing blogs as information sources for libraries and information science. In M. Khosrow-Pour (Ed.), Encyclopedia of Information Science and Technology, 3rd Edition. Hershey, PA: Information Science Reference, 4833-4845. doi:10.4018/9781-4666-5888-2.ch475.

Sibona, $\mathrm{C}$ and Choi, J.H. 2012. Factors affecting end-user satisfaction on Facebook. Proceedings of the 6th International AAAI Conference on Weblogs and Social Media (ICWSM). Available at: https://www.aaai.org/ocs/index.php/ICWSM/ICWSM12/paper/view/4569/5061.

Sin, S.C. J. and Kim, K. S. 2013. International students' everyday life information seeking: The informational value of social networking sites. Library \& Information Science Research, Vol. 35 no. 2: 107-116. doi:10.1016/j.lisr.2012.11.006

Smith, A., Rainie, L. and Zickuhr, K. 2011. College students and technology. Available at: http://www.pewinternet.org/2011/07/19/college-students-and-technology/

Tri-Agif, I.A., Noorhidawati, A. N. and Ghalebandi, S. G. 2016. Continuance intention of using e-book among higher education students. Malaysian Journal of Library \& Information Science, Vol. 21 no. 1: 19-33.

Zha, X., Wang, W., Yan, Y., Zhang, J. and Zha, D. 2015. Understanding information seeking in digital libraries: antecedents and consequences. Aslib Journal of Information Management, Vol. 67 no.6: 715-734.

Zohoorian-Fooladi, N. and Abrizah, A. 2014. Academic Librarians and their Social Media Presence: A Story of Motivations and Deterrents. Information Development, Vol. 30 no. 2: 159-171. 